\title{
Determination of total phenolic and total flavonoid contents and antioxidant capacities of an aquatic plant (Riccia fluitans)
}

\section{Aquatik bir bitkinin (Riccia fluitans) toplam fenolik ve toplam flavonoid içeriklerinin ve antioksidan kapasitelerinin belirlenmesi}

\author{
Semra Türkoğlu1* • Akif Evren Parlak ${ }^{2}$ \\ ${ }^{1}$ Firat University, Elazig School of Health, Elazig, Turkey \\ 2Firat University, Keban Vocational School of Higher Education, Elazig, Turkey \\ ${ }^{*}$ Corresponding author: smrturkoglu@hotmail.com
}

How to cite this paper:

Türkoğlu, S., Parlak, A.E., 2014. Determination of total phenolic and total flavonoid contents and antioxidant capacities of an aquatic plant (Riccia fluitans). Ege J Fish Aqua Sci 31(1): 35-40. doi: 10.12714/egejfas.2014.31.1.06

Özet: Genel adı crystalwort olan Riccia fluitans, akvaryum bitkileri arasında popüler olan Riccia kızlyaprak cinsinden suda yüzen bir bitkidir. Riccia fluitans sık sık su yüzeyinde ve altında kalın paspaslar oluşturarak ve havuzlarda yüzüyor olarak bulunabilir.

Bu çalışmanın amacı, Riccia fluitans' in farklı in vitro yöntemlerle antioksidan aktivitelerinin belirlenmesidir. Antioksidan ve antiradikal aktiviteler değerlendirilmesi için, ABTS++ (2,2 '-azino - bis (3- etilenbenztiyazolin -6-sülfonik asit) radikali giderme aktivitesi, DPPH• (1,1- difenil-2- pikril-hidrazil) serbest radikal giderme aktivitesi, indirgeme kuvveti ve demir iyonları şelatlama aktiviteleri hesaplandı. a -tokoferol referans antioksidan bileşik olarak kullanılmıştır. Buna ek olarak, etanol ekstrelerinde toplam fenolik ve toplam flavonoid bileşikler sırasıyla, gallik asit ve kuersetin eşdeğerleri olarak belirlenmiştir. Sonuç olarak, bu bitki doğal gıda antioksidan umut verici bir kaynağıdır .

Anahtar kelimeler: Riccia fluitans, Antioksidan, Toplam fenolik, Toplam flavonoid.

Abstract: Riccia fluitans, whose common name is crystalwort, is an aquatic floating plant of the liverwort genus Riccia which is popular among aquarist plants. It can be found floating in ponds, and often forms thick mats on and under the water surface.

The objective of this study made to determine the antioxidant activities of Riccia fluitans using different in vitro methods. For evaluation of antioxidant and antiradical activities, $\mathrm{ABTS}^{+}$(2,2'-azino-bis(3-ethylbenzthiazoline-6-sulfonic acid)) radical scavenging activity, $\mathrm{DPPH}$ (1,1-diphenyl-2-picryl-hydrazyl) free radical scavenging activity, reducing power, and ferrous ions chelating activities were calculated. a-tocopherol were used as the reference antioxidant compound. In addition, the total phenolic and total flavonoid compounds in ethanol extracts were determined as gallic acid and quercetin equivalents, respectively. Consequently, this plant is a promising source of natural food antioxidants.

Keywords: Riccia fluitans, Antioxidant, Total Phenolic, Total Flavonoid.

\section{INTRODUCTION}

Riccia fluitans, whose common name is crystalwort, is an aquatic floating plant of the liverwort genus Riccia which is popular among aquarists as a retreat for young fry and is used in live-bearing tanks. It can be found floating in ponds, and often forms thick mats on and under the water surface.

It normally grows quickly at the surface. When kept about two to three inches below an ordinary fluorescent bulb or in a pond exposed to full sunlight, it will form dense, bright green mats. Any single branch or antler bud can reproduce into a large colony if the plant is kept in proper conditions. It normally floats, but can also be attached to underwater objects such as logs and rocks.

Free radicals play a crucial role in the development of tissue damage in various human diseases such as cancer, aging, neurodegenerative disease, malaria and

(c) Published by Ege University Faculty of Fisheries, Izmir, Turkey arteriosclerosis, and pathological events in living organisms (Gutteridge, 1994). Antioxidants may have an important role in the prevention of these diseases. There is an increasing interest in the antioxidant effects of compounds derived from plants, which could be relevant in relation to their nutritional incidence and their role in health and disease (Pieroni et al. 2002; Couladis et al. 2003). A number of reports on the isolation and testing of plantderived antioxidants have been described during the past decade. Natural antioxidants constitute a broad range of substances including phenolic or nitrogen containing compounds and carotenoids (Shahidi et al. 1992; Velioglu et al. 1998; Pietta et al. 1998).

Liverwort $R$. fluitans is a widespread plant, but has not been thoroughly studied yet. 
Literature reports (Stodola 1967) that $R$. fluitans can be used as animal feed. Cecal et al. (2002) investigated bioaccumulation of radioactive zinc ions from aqueous solutions by hydrophytic plants, including $R$. fluitans. The authors found that $R$. fluitans bound the highest quantities of metal ions. Also, the mechanism of the process was studied.

Chojnacka (2007) investigated the potential applicability of a liverwort $R$. fluitans for the production of biological mineral

supplement. Author discussed binding of minerals of feeding significance $(\mathrm{Mn}, \mathrm{Zn}, \mathrm{Cu}, \mathrm{Cr})$ to the biomass with the use of various processes: biosorption and bioaccumulation by nongrowing and growing cells. Also, the mechanism of the process was discussed. And it was found that $R$. fluitans was rich in protein and possessed high cation-exchange capacity that predisposed the plant to have the potential to be applied as biological mineral supplement-biological material to which minerals can be bound and be supplied to animals in biologically available form.

As far as our literature survey could ascertain, no prior information was available on the in vitro total antioxidant activity, reducing power, DPPH radical scavenging, ABTS* radical scavenging, or metal chelating activities of $R$. fluitans (Crystalwort) extracts given here. Furthermore, extracts total phenolic and total flavonoid content were also investigated.

The aim of the present study was to investigate the potential antioxidant capacity and content of total phenolic and total flavonoid of a liverwort $R$. fluitans (Crystalwort) use for minimizing or preventing lipid oxidation in food products, retarding the formation of toxic oxidation products, maintaining nutritional quality and prolonging the shelf-life of foods and pharmaceuticals and also for the production of biological mineral supplement.

\section{MATERIALS AND METHOD}

\section{Experimental procedures}

Nearly $100 \mathrm{~g}$ crystalwort (Riccia fluitans) were put into test aquarium. Test medium were renewed twice a week with freshly prepared one.

\section{Plant material and extraction procedure}

Extraction was carried out as described previously (Gulcin et al. 2004). Riccia fluitans were shade-dried initially. In order to determine the ethanol extraction, a $25 \mathrm{~g}$ sample of Riccia fluitans was ground into a fine powder in a mill and mixed with $500 \mathrm{~mL}$ of ethanol, and then evaporated. The residue was reextracted under the same conditions until extraction solvents became colorless. The obtained extracts were filtered through Whatman No. 1 paper and the filtrate was collected; then the ethanol was removed using a rotary evaporator to obtain a dry extract. Extracts were placed in a plastic bottle (PETP-color and capped bottle for storage) and then stored at $-20^{\circ} \mathrm{C}$ until used.

\section{Determination of total phenolic content and total flavonoid}

Total phenolic concentration in the extract was determined spectrophotometrically according to the Folin-Ciocalteu method (Singleton et al. 1999). The total phenolic content was calculated from the calibration curve using gallic acid as a standard and the results were expressed as milligram of gallic acid equivalents per gram dry weight of extract (mg GAE/g d.w.) for the dried extract. Determination of total phenolic in this assay was based on their chemical reducing capacity relative to an equivalent reducing capacity of gallic acid (Katalinic et al. 2006).

Briefly, $1 \mathrm{mg} / \mathrm{mL}$ of each extract was added in a universal bottle followed by $1 \mathrm{~mL}$ of Folin-Ciocalteu reagent (F9252Sigma-Aldrich). The content of the bottle was mixed thoroughly. After $3 \mathrm{~min}, 3 \mathrm{~mL}$ of sodium carbonate was added and the mixture was allowed to stand for $2 \mathrm{~h}$ at room temperature $\left(25^{\circ} \mathrm{C}\right)$ in the dark. This test is sensitive to light. The absorbance was measured at $760 \mathrm{~nm}$ in a spectrophotometer. The amounts of total phenolic compounds in the Riccia fluitans extract were determined as micrograms of gallic acid equivalent, using an equation. The same procedure was repeated for all standard gallic acid solutions at different concentrations $(0,0.05,0.1,0.15$ and $0.2 \mathrm{mg} / \mathrm{mL})$. Data presented were averaged for triplicate measurements.

The amounts of total flavonoid in extract were determined as follows: the Riccia fluitans extract solutions (1 mg) were diluted with $4.3 \mathrm{~mL}$ of ethanol containing $0.1 \mathrm{~mL}$ of $10 \%$ aluminum nitrate and $0.1 \mathrm{~mL}$ of $1 \mathrm{M}$ aqueous potassium acetate. After $40 \mathrm{~min}$ of incubation at room temperature, the absorbance was determined spectrophotometrically at 415 $\mathrm{nm}$.

\section{Total reduction capability}

The stock samples prepared for the ferric thiocyanate method were used for this and other assays. The reducing power of Riccia fluitans was determined by Oyaizu's method (Oyaizu, 1986). Extract of Riccia fluitans $(100 \mu \mathrm{g} \mathrm{mL}-1)$ in $1 \mathrm{~mL}$ of distilled water were mixed with $2.5 \mathrm{~mL}$ of phosphate buffer (0.2 M, pH 6.6) and potassium ferricyanide $\left[\mathrm{K}_{3} \mathrm{Fe}(\mathrm{CN})_{6}\right](2.5$ $\mathrm{mL}, 1 \%$ ). The mixture was incubated at $50{ }^{\circ} \mathrm{C}$ for $20 \mathrm{~min}$. Aliquots $(2.5 \mathrm{~mL})$ of trichloroacetic acid $(10 \%)$ were added to the mixture. The upper layer of solution $(2.5 \mathrm{~mL})$ was mixed with distilled water $(2.5 \mathrm{~mL})$ and $\mathrm{FeCl}_{3}(0.5 \mathrm{~mL}, 0.1 \%)$, and the absorbance was measured at $700 \mathrm{~nm}$ in a spectrophotometer. The mean absorbance values were plotted against the concentration and a linear regression analysis was carried out. Increased absorbance of the reaction mixture indicates an increase in reduction capability. 


\section{Chelating activity of ferrous ions $\left(\mathrm{Fe}^{2+}\right)$}

The chelating of ferrous ions by extract of Riccia fluitans, and the standards was performed according to the method of Dinis et al. (1994). The reaction was performed in an aqueous medium. Briefly, extract of Riccia fluitans $(100 \mu \mathrm{g} \mathrm{mL}-1)$ in 0.4 $\mathrm{mL}$ was added to a solution of $2 \mathrm{mM} \mathrm{FeCl} 2(0.2 \mathrm{~mL})$. The reaction was initiated by the addition of $5 \mathrm{mM}$ ferrozine $(0.4$ $\mathrm{mL}$ ) and the total volume was adjusted to $4 \mathrm{~mL}$ of ethanol. Then the mixture was shaken vigorously and left at room temperature for $10 \mathrm{~min}$. Absorbance of the solution was then measured spectrophotometrically at $562 \mathrm{~nm}$. The percentage of the inhibition of ferrozine-Fe ${ }^{2+}$ complex formation was calculated by using the following formula:

Ferrousion $\left(\mathrm{Fe}^{+2}\right)$ chelating effect (\%): 1- $\mathrm{A}_{s} / \mathrm{A}_{c} \times 100$

where $A_{c}$ is the absorbance of control and $A_{s}$ is the absorbance in the presence of extract of Riccia fluitans, or the standards. The control contains $\mathrm{FeCl}_{2}$ and ferrozine, complex formation molecules (Gulcin et al. 2006b).

\section{Radical scavenging activity}

Free radical scavenging capacity of extract of Riccia fluitans was determined and compared to that of a-tocopherol by using the $\mathrm{DPPH} \cdot \mathrm{ABTS}^{\circ}$, and superoxide anion radical scavenging methods.

\section{DPPH' free radical scavenging activity.}

The DPPH' assay provides basic information on the antiradical activity of the extract. The radical scavenging activity of the extract of Riccia fluitans was determined spectrophotometrically by monitoring the disappearance of $\mathrm{DPPH}^{\cdot}$ at $517 \mathrm{~nm}$, according to the methodology of Blois (1958), previously described by Gulcin et al. (Gulcin et al. 2006a). The bleaching rate of a stable free radical, DPPH', is monitored at a characteristic wavelength in the presence of the sample. In its radical form, DPPH absorbs at $517 \mathrm{~nm}$, but upon reduction by an antioxidant or a radical species its absorption decreases. Briefly, a $0.1 \mathrm{mM}$ solution of $\mathrm{DPPH}^{\cdot}$ $\left(10^{-3} \mathrm{M}\right)$ was prepared in ethanol and $0.5 \mathrm{~mL}$ of this solution was added to $1.5 \mathrm{~mL}$ of extract of Riccia fluitans solution in ethanol at concentration $100 \mu \mathrm{g} \mathrm{mL} \mathrm{L}^{-1}$. These solutions were vortexed thoroughly and incubated in the dark. Thirty minutes later, the absorbance was measured at $517 \mathrm{~nm}$ against the blank samples. The lower absorbance of the reaction mixture indicates higher DPPH free radical scavenging activity.

The mean inhibitory concentration (IC50), which is the concentration of extract needed to decrease the initial absorbance of $\mathrm{DPPH} \cdot$ by $50 \%$ was determined graphically.

\section{$\mathrm{ABTS}^{++}$radical cation decolorization assay.}

The spectrophotometric analysis of the ABTS++ radical scavenging activity of extract of Riccia fluitans was determined according to the method of Re et al. (1999). This method is based on the ability of antioxidants to quench the long-lived $\mathrm{ABTS}^{++}$radical cation, a blue/green chromophore with characteristic absorption at $734 \mathrm{~nm}$. The ABTS++ cation radical was produced by the reaction between $2 \mathrm{mM} \mathrm{ABTS}++$ in $\mathrm{H}_{2} \mathrm{O}$ and $2.45 \mathrm{mM}$ potassium persulfate, stored in the dark at room temperature for $4 \mathrm{~h}$. Before usage, the ABTS*+ solution was diluted to achieve an absorbance of $0.750 \pm 0.025$ at $734 \mathrm{~nm}$ with a phosphate buffer $(0.1 \mathrm{M}, \mathrm{pH} 7.4)$. Then $1 \mathrm{~mL}$ of $\mathrm{ABTS}^{+}$solution was added to $3 \mathrm{~mL}$ of extract of Riccia fluitans solution in ethanol at concentration $100 \mu \mathrm{g} \mathrm{mL}-1$. After $30 \mathrm{~min}$, the percentage inhibition at $734 \mathrm{~nm}$ was calculated for each concentration relative to a blank absorbance. Solvent blanks were run in each assay. The extent of decolorization was calculated as the percentage of reduction of absorbance.

\section{ABTS•+ (\%) inhibition: 1- As/Ac x 100}

where $A c$ is the initial concentration of the ABTS ${ }^{*+}$ and As is the absorbance of the remaining concentration of $A B T S^{++}$in the presence of extract of Riccia fluitans (Gulcin, 2006c).

\section{Statistical analyses}

All analyses were performed in triplicate. The parametervalues were all expressed as the mean 5$\}$ standard deviation (SD). Significant differences among the groups were determined by one-way ANOVA using the SPSS 12.0 program.

\section{RESULTS AND DISCUSSION}

Total phenolic content of the extract Riccia fluitans was determined using Folin-Ciocalteu colorimetric method by manipulating the regression equation of gallic acid calibration curve. The amount of phenolic per each extract was expressed as gallic acid equivalent. The results obtained from the assay were expressed as means \pm standard deviation of triplicate analyses and are presented in Table 1.

Table 1. Total phenolic content and total flavonoid content of Riccia fluitans extract

\begin{tabular}{ccc}
\hline Extracts & $\begin{array}{c}\text { Total phenolic } \\
\left(\mu \mathrm{g} \mathrm{mg}^{-1} \mathrm{extract}\right)\end{array}$ & $\begin{array}{c}\text { Total flavonoid } \\
\left(\mu \mathrm{g} \mathrm{mg}^{-1} \mathrm{extract}\right)\end{array}$ \\
\hline R.flutians & $16.6 \pm 4.3$ & $10.6 \pm 4.1$ \\
\hline
\end{tabular}

The total phenolic content of Riccia fluitans extract are shown in Table 1. For determining the total phenolic contents, calibration curves were obtained using known quantities of standard gallic acid. The phenolic compound of $1 \mathrm{mg}$ of Riccia fluitans was determined and found to be $16.6 \pm 4.3$. The content of total flavonoid in Riccia fluitans was determined spectrophotometrically and found to be $10.6 \pm 4.1$. 
Table 2 shows the reducing power of the Riccia fluitans extract, and standards (a-tocopherol) using the potassium ferricyanide reduction method. Riccia fluitans extract showed an effective reducing power (Table 2). The reducing power of Riccia fluitans extract, and the standard compounds exhibited the following order: a-tocopherol>Riccia fluitans.

As seen in Table 2, extract had effective ABTS*+ radical scavenging activity in a concentration $(100 \mu \mathrm{g} \mathrm{mL}-1)$ the scavenging effect of extract of Riccia fluitans, and the standards on the ABTS ${ }^{++}$decreased in that order: atocopherol>Riccia fluitans at the concentration of $100 \mu \mathrm{g} \mathrm{mL}^{-1}$.

Table 2. Reductive potential and ABTS++ radical scavenging activity of Riccia fluitans extract and a-tocopherol at the concentration of $100 \mu \mathrm{g} \mathrm{mL}^{-1}$

\begin{tabular}{ccc}
\hline Extracts & $\begin{array}{c}\text { Reductive potential of } \\
\text { Riccia fluitans }(\mathbf{7 0 0} \mathrm{nm})\end{array}$ & $\begin{array}{c}\text { ABTS+ radical scavenging } \\
\text { activity of Riccia fluitans } \\
(734 \mathrm{~nm})\end{array}$ \\
\hline $\begin{array}{c}\text { R. flutians } \\
\begin{array}{c}\boldsymbol{\alpha}- \\
\text { tocopherol }\end{array}\end{array}$ & $0,247 \pm 0,019$ & $0,383 \pm 0,026$ \\
\hline
\end{tabular}

Table 3 illustrates a significant decrease $(P<0.001)$ in the concentration of the $\mathrm{DPPH}^{\cdot}$ radical due to the scavenging ability of Riccia fluitans extract and the standard. a-tocopherol were used as references for radical scavengers. The scavenging effect of Riccia fluitans extract, and the atocopherol on the DPPH radical decreased in the order of atocopherol> Riccia fluitans. Extract of Riccia fluitans exhibited effectual radical cation scavenging activity.

The ferrous ion chelating activities of Riccia fluitans extract, and a-tocopherol are shown in Table 3. The metal chelating effect of samples in the order of atocopherol>R.flutians. The data obtained from Table 3 reveal that Riccia fluitans extract demonstrate a marked capacity for iron binding, suggesting that their main action as peroxidation protectors may be related to their iron binding capacity.

Table 3. Ferrous ion chelating activity and $\mathrm{DPPH} \cdot$ free radical scavenging activities of concentrations $\left(100 \mu \mathrm{g} \mathrm{mL}^{-1}\right)$ of extract of Riccia fluitans and $\alpha$ - tocopherol

\begin{tabular}{ccc}
\hline Extracts & Ferrous ion chelating activity (\%) & $\mathrm{DPPH} / \boldsymbol{C}_{50}$ \\
\hline R. flutians & $38.8 \pm 4.9$ & 21.4 \\
a-tocopherol & $70,9 \pm 7,1$ & 5.1 \\
\hline
\end{tabular}

In recent years, extracts of some plants have gained special interest as sources of natural antioxidant agents. Such products are also rich in fiber, have no cholesterol and contain antioxidants such as carotenoids and flavonoid and other phenolic compounds. Flavonoid are an important group of natural compounds, which can prevent coronary heart disease and have antioxidant properties. It has been reported that flavonoid represent a class of naturally occurring compounds, mainly found in fruits, vegetables, and cereals (Hsieh and Kinsella 1989). It has been further reported that phenolic compounds are associated with antioxidant activity. According to other reports, a highly positive relationship between total phenols and antioxidant activity was found in many plant species (Gulcin, 2005; Turkoglu et al. 2010). Different results have been reported about this; some authors have found a correlation between phenolic content and antioxidant activity (Yang et al. 2002; Gulcin et al. 2010). Total antioxidant capacity is widely used as a parameter for food, pharmaceutical, and medicinal extracts. In this study, the antioxidant activity of extract of Riccia fluitans was compared to that of a-tocopherol. The antioxidant activity of the extract of Riccia fluitans, and a-tocopherol has been evaluated in a series of in vitro tests: DPPH' free radical scavenging, ABTS*+ radical scavenging, non-enzymatic systems, reducing power by $\mathrm{Fe}^{3+}-\mathrm{Fe}^{2+}$ transformation, and metal chelating activities.

$\mathrm{Fe}^{3+}-\mathrm{Fe}^{2+}$ transformation was investigated to determine the measurements of the reductive ability of extract of Riccia fluitans by using the method of Oyaizu (1986). Its results on the reducing power demonstrate the electron donor properties of extract of Riccia fluitans, thereby neutralizing free radicals by forming stable products. The outcome of the reducing reaction is to terminate the radical chain reactions that may otherwise be very damaging.

Chelation of ferrous ions $\left(\mathrm{Fe}^{2+}\right)$ may provide important antioxidative effects by retarding metalcatalyzed oxidation. Among the transition metals, iron is known as the most important lipid oxidation pro-oxidant due to its high reactivity. The effective ferrous ion chelators may also afford protection against oxidative damage by removing iron $\left(\mathrm{Fe}^{2+}\right)$ that may otherwise participate in an $\mathrm{HO}^{\circ}$ generating Fenton reaction.

Ferric $\left(\mathrm{Fe}^{3+}\right)$ ions also produce radicals from peroxides, although the rate is 10 -fold less than that of ferrous $\left(\mathrm{Fe}^{2+}\right)$ ions (Gulcin et al. 2010). The $\mathrm{Fe}^{2+}$ ion is the most powerful prooxidant among the various species of metal ions. $\mathrm{Fe}^{2+}$ is able to generate free radicals from peroxides by Fenton reactions and may be involved in the progression of human cardiovascular disease. Thus, antioxidants capable of chelating with $\mathrm{Fe}^{2+}$ will minimize the ion's concentration and inhibit its capacity to catalyze free radical formation, which will result in protection against oxidative damage. Ferrozine can quantitatively form complexes with $\mathrm{Fe}^{2+}$. In the presence of chelating agents, the complex formation is disrupted, resulting in a decrease in the red color of the complex. Measurement of color reduction therefore allows for the estimating of the metal chelating activity of the coexisting chelator. In this assay, extract of Riccia fluitans are interfered with by the formation of ferrous and ferrozine complexes, suggesting that they possess chelating activities and are able to capture ferrous ion before ferrozine.

$\mathrm{DPPH}^{\cdot}$ is a long-lived nitrogen radical. Many antioxidants that react quickly with transient radicals, such as peroxyl radicals, may react slowly or may even be inert to DPPH' (Gulcin, 2009; Gulcin et al. 2010). $\mathrm{DPPH} \cdot$ has also been widely used for the evaluation of free radical scavenging effectiveness of various antioxidant substances (Ak and Gulcin, 2008). In the $\mathrm{DPPH} \cdot$ assay, the antioxidants were able to reduce the stable radical $\mathrm{DPPH}^{\cdot}$ to the yellow-colored diphenyl- 
picrylhydrazine. This method is based on the reduction of an alcoholic DPPH solution in the presence of a hydrogen-donating antioxidant due to the formation of the non-radical form DPPH-H by the reaction. $\mathrm{DPPH}^{\cdot}$ is usually used as a reagent to evaluate the free radical scavenging activity of antioxidants (Oyaizu, 1986). Generation of the ABTS *+ radical cation forms the basis of one of the spectrophotometric methods that have been applied to the measurement of the total antioxidant activity of solutions of pure substances, aqueous mixtures, and beverages (Gulcin et al. 2006a; Koksal et al. 2008). A more appropriate format for the assay is a decolorization technique in which the radical is generated directly in a stable form prior to reaction with putative antioxidants. The improved technique for the generation

\section{REFERENCES}

Ak, T., Gulcin, İ., 2008. Antioxidant and radical scavenging properties of curcumin. Chemico-Biological Interactions. 174: 27-37. doi: 10.1016/j.cbi.2008.05.003

Blois, M.S., 1958. Antioxidant determinations by the use of a stable free radical. Nature. 26: 1199-1200. doi:10.1038/1811199a0

Cecal, A., Popa, K., Caraus, I., Potoroaca, V., 2002. Bioaccumulation of ${ }_{65} \mathrm{Zn}^{2+}$ ions by some hydrophytic plants. Isotopes in Environmental and Health Studies. 38: 33-37.

Chojnacka, K., 2007. Biosorption and bioaccumulation of microelements by Riccia Xuitans in single and multi-metal system. Bioresource Technology. 98: 2919-2925. doi: 10.1016/j.biortech.2006.10.001

Couladis, M., Tzakou, O., Verykokidou, E., Harvala, C., 2003. Screening of some Greek aromatic plants for antioxidant activity. Phytotherapy Research. 17: 194-195. doi: 10.1002/ptr.1261

Dinis, T.C.P., Madeira, V.M.C., Almeida, L.M., 1994. Action of phenolic derivates (acetoaminophen, salycilate, and 5-aminosalycilate) as inhibitors of membrane lipid peroxidation and as peroxyl radical scavengers. Archives of Biochemistry and Biophysics. 315: 161-169. doi: 10.1006/abbi.1994.1485

Gutteridge, J.M.C., 1994. Biological origin of free radicals and mechanisms of antioxidant protection. Chemico-Biological Interactions. 91: 133-140. doi:10.1016/0009-2797(94)90033-7

Gulcin, I., Elias, R., Gepdiremen, A., Boyer, L., 2006a. Antioxidant activity of lignans from fringe tree (Chionanthus virginicus L.). European Food


doi: 10.1007/s00217-006-0265-5

Gulcin, I., Kirecci, E., Akkemik, E., Topal, F., Hisar, O., 2010. Antioxidant, antibacterial, and anticandidal activities of an aquatic plant: duckweed (Lemna minor L. Lemnaceae). Turkish Journal of Biology. 34: 175-188.

Gulcin, I., Mshvildadze, V., Gepdiremen, A., Elias, R., 2006b. Screening of antioxidant and antiradical activity of monodesmosides and crude extract from Leontice smirnowii Tuber. Phytomedicine. 13: 343-51. doi:10.1016/j.phymed.2005.03.009

Gulcin, I., Sat, I.G., Beydemir, S., Kufrevioglu, I., 2004. Evaluation of the in vitro antioxidant properties of extracts of broccoli (Brassica oleracea L.). Italian Journal of Food Science. 16: 17-30.

Gulcin, I., 2006c. Antioxidant activity of caffeic acid (3,4- dihydroxycinnamic acid). Toxicology. 217: 213-220. doi: 10.1016/j.tox.2005.09.011 of $\mathrm{ABTS}^{\cdot+}$ described here involves the direct production of the blue/green ABTS ++ chromophore through the reaction between $\mathrm{ABTS}^{++}$and potassium persulfate (Gulcin, 2006c).

\section{CONCLUSION}

According to data of the present study, extract of Riccia fluitans were found to be effective antioxidants and antiradicals Moreover, our studies showed that extract of Riccia fluitans are good sources of antioxidants for food, medicines, and pharmaceuticals. Based on the discussion above, these extracts can be use for minimizing or preventing lipid oxidation in food products, retarding the formation of toxic oxidation products, maintaining nutritional quality and prolonging the shelf-life of foods and pharmaceuticals.

Gulcin, I., 2009. Antioxidant activity of L-Adrenaline: An activity structure insight. Chemico-Biological Interactions. 179: 71-80. doi: 10.1016/j.cbi.2008.09.023

Gulcin, I., 2006a. Comparison of in vitro antioxidant and antiradical activities of L-tyrosine and L-Dopa. Amino Acids. 32: 431-438. doi: 10.1007/s00726-006-0379-x

Gulcin, I., 2005. The antioxidant and radical scavenging activities of black pepper (Piper nigrum) seeds. International Journal of Food Sciences and Nutrition. 56: 491-499. doi:10.1080/09637480500450248

Hsieh, R.J., Kinsella, J.E., 1989. Oxidation of polyunsaturated fatty acids: Mechanisms, products, and inhibition with emphasis on fish. Advances in Food and Nutrition Research. 33: 233-241. doi:10.1016/S1043-4526(08)60129-1

Katalinic, V., Milos, M., Kulisic, T., Jukic, M., 2006. Screening 70 medicinal plant extracts for antioxidant capacity and total phenols. Food Chemistry. 94: 550-557. doi: 10.1016/j.foodchem.2004.12.004

Koksal, E., Gulcin, I., Ozturk, S.B., Bursal, E., 2008. On the in vitro antioxidant activity of silymarin. Journal of Enzyme Inhibition and Medicinal Chemistry. 24: 395-405. doi: 10.1080/14756360802188081

Oyaizu, M., 1986. Studies on product of browning reaction prepared from glucose amine. Japanese Journal of Nutrition. 44: 307-315. doi:10.5264/eiyogakuzashi.44.307

Pieroni, A., Janiak, V., Durr, C.M., Ludeke, S., Trachsel, E., Heincrich, M., 2002. In vitro antioxidant activity of non-cultivated vegetables of ethnic Albanians in Southern Italy. Phytotherapy Reseach. 16: 467-473. doi: $10.1002 / p t r .1243$

Pietta, P., Sionetti, P., Mauri, P., 1998. Antioxidant activity of selected medicinal plants. Journal of Agricultural and Food Chemistry. 46: 44874490. doi: 10.1021/j980310p

Re, R., Pellegrini, N., Proteggente, A., Pannala, A., Yang, M., Rice-Evans, C., 1999. Antioxidant activity applying an improved ABTS radical cation decolorization assay. Free Radical Biology \& Medicine. 26: 1231-1237. doi: 10.1016/S0891-5849(98)00315-3

Shahidi, F., Janitha, P.K., Wanasundara, P.D., 1992. Phenolic antioxidants. Critical Reviews in Food Science and Nutrition. 32: 67-103. doi: 10.1080/10408399209527581

Singleton, V.L., Orthofer, R., Lamuela-Raventos, R.M., 1999. Analysis of total phenols and other oxidation substrates and antioxidants by means of Folin-Ciocalteu reagent. Methods in Enzymology. 299: 152-178. doi: 10.1016/S0076-6879(99)99017-1 
Stodola, J., 1967. Encyclopedia of Water Plants. TFH Publications. Neptune City, New Jersey, p 366.

Turkoglu, I., Turkoglu, S., Celik, S., Kahyaoglu, M., 2010a. Antioxidant and Antimicrobial Activities of Turkish Endemic Achillea Species. African Journal of Microbiology Research. 4: 2034-2042.
Velioglu, Y.S., Mazza, G., Gao, Y.L., Oomah, B.D., 1998. Antioxidant activity and total phenolics in selected fruits, vegetables and grain products. Journal of Agricultural and Food Chemistry. 46: 4113-4117. doi: $10.1021 / \mathrm{j} f 9801973$

Yang, J.H., Lin, H.C., Mau, J.L., 2002. Antioxidant properties of several commercial mushrooms. Food Chemistry. 77: 229-235. doi: 10.1016/S0308-8146(01)00342-9 